\title{
Economic Interaction Between Malaysia and North Sumatra: An Analysis With Vector Error Correction Model and Granger Causality
}

Submitted 10/12/18, $1^{\text {st }}$ revision 25/1/19, $2^{\text {nd }}$ revision 26/2/19 accepted 29/3/19

\author{
Muhammad Nasir ${ }^{1}$
}

\begin{abstract}
:
Purpose: This study aims to explain the economic interaction of North Sumatra province in Indonesia with the Malaysian economy and vice versa. The variables studied were the North Sumatra PDRB proxy from the economy of North Sumatra, Malaysia's GDP proxy from the Malaysian economy, Export-Import from both regions.

Design/methodology/approach: This study uses time series data from 1990-2016. Test and analysis tools use descriptive statistics, ordinary least square (OLS), unit root tests, cointegration tests, vector error correction models (VECM), impulse response functions, granger causality tests.

Findings: The results show that Malaysia's economy has a positive and significant impact on North Sumatra's exports to Malaysia, and North Sumatra's exports to Malaysia have a positive and significant impact on Malaysian exports to North Sumatra, meaning there is a two-way relationship. Moreover, North Sumatra's exports to Malaysia have a negative and significant impact on Malaysia's economy.

Practical implications: The results show that the increasing economy of North Sumatra caused an increase in North Sumatra imports from Malaysia as well as an increase in Malaysia's economy which led to an increase in Malaysian imports from North Sumatra.

Originality/value: This study shows the economic interaction and trade relationship analysis between neighbouring regions with multiple examinations of Vector Error Correction Model And Granger Causality.
\end{abstract}

Keywords: Economic interaction, trade relations, neighbouring regions, vector error correction model and granger causality.

Paper type: Research paper.

\footnotetext{
${ }^{1}$ Faculty of Economics, Universitas Negeri Medan Jl. Williem Iskandar Ps. V Medan 20221, Indonesia Telp. +6261-6613365, E-mail: mnasir.unimed@gmail.com
} 


\section{Introduction}

Malaysia is a country where the area is adjacent to the province of North Sumatra, bordering the Malacca Strait. This country has been visited by many workers from northern Sumatra to get jobs, this region has an electronic industry that requires a lot of labor. North Sumatra is one of Indonesia's republican provinces located in the western part of Indonesia, neighboring to the territory of Malaysia, the closeness of the two regions has resulted in economic interaction between the two regions. North Sumatra's export volume in 2016 amounted to 8,387,357 tons and its value reached US $\$ 7,770,742$ thousand and North Sumatra's exports to Malaysia amounted to US $\$ 242,504,000$ in presentation at $3.12 \%$. The volume of North Sumatra imports in 2016 amounted to $6,819,193$ tons with a value of US $\$ 3,914.49$ million. The volume of imports of North Sumatra from Malaysia was US \$389,811,000.

North Sumatra's main export commodities are vegetable oils and animal fats and products that have not been processed and there are also industrial products. On the contrary, imported products from North Sumatra are in the form of raw materials, auxiliary materials, consumption products, and capital goods. North Sumatra has natural resources which have not been optimally exploited. This is attractive to investors. Besides North Sumatra lies in a strategic geographical position, this region is very efficient for the location of the center of economic activity. The population of North Sumatra in 2015 amounted to 13,937,797 people. This number is expected to encourage economic growth, in accordance with the opinion of classical economists that the variable population size affects economic growth in an area, with economic growth being expected to increase profits for investors.

North Sumatra and Malaysia in a geographic manner as neighboring regions will interact with each other. Malaysia's industrial activities constitute an economic sector which plays an important role in the country's GNP. This requires natural resources and employment. On the other hand, North Sumatra has natural resources and a sizeable population. From this phenomenon it is expected that North Sumatra is one of the suppliers' sources for meeting the needs of natural resources and labor for the Malaysian state. On the other hand, North Sumatra still lacks capital goods and auxiliary goods. Malysia countries, especially investors can make investments in northern Sumatra, mutual symbiosis of the relations between the two regions will provide benefits for each region.

Bendavid (1991) states that the linkages between regions in the economic field can be in the form of the flow of goods, intermediate goods, final goods, consumer spending, income streams including transfers and transfers of money, capital flows, seasonal labor migration. Based on the identification and exposure of the phenomena that have been described (Nasir, 2017), this research aims to identify the effect of Malaysia's real investment on the economy of North Sumatra and the causal relationship between exports - imports, the Malaysian economy and the economy of North Sumatra. 


\section{Economic Interaction Between Neighboring Regions}

Regions whose geographic location is neighboring can interact with each other including economic aspects (Wijaya et al., 2017). Audretsch (2004) found that geographical proximity plays an important role in the process of reciprocity for innovative activities, namely the expansion of knowledge. Athukorala and Yamashita (2006) conducted a study in the United States and Asia Pacific regions to find that there was a reciprocal linkage between the United States and the Asia Pacific region in the form of trade, investment, finance through the stock market. Likewise Glaeser at al (1992) describes that the externality of geographical proximity is knowledge transfer (knowledge spillover) acts as an important determinant of economic growth. Other researchers Cheshiro and Carbonaro (1996) suggest that one or the determining factor of regional economic growth is the influence of neighboring regions called spilover effects from other regions.

Mody and Wang (1997) revealed that regions that are geographically adjacent to regions that have a high level of economic growth can be influenced by high growth rates. Furthermore, Rahman (2008) conducted research in the countries of SAARC (Bangladesh, India, Nepal, Pakistan and Sri Lanka), the results showed that regional trade, namely export-import in regions that have geographical proximity affect the economy of neighboring countries and mutual benefits and increase the income of these countries. Nasir (2015) conducted research on the economic relations of neighboring Singapore with North Sumatra Province in Indonesia, concluding that there was a one-way relationship between Singapore's economy and North Sumatra's economy in Indonesia. Based on the description above, a simple scheme can be made which shows the relationship between the variables under study.

Figure 2. Scheme of Economic Variable Relations that Are Examined

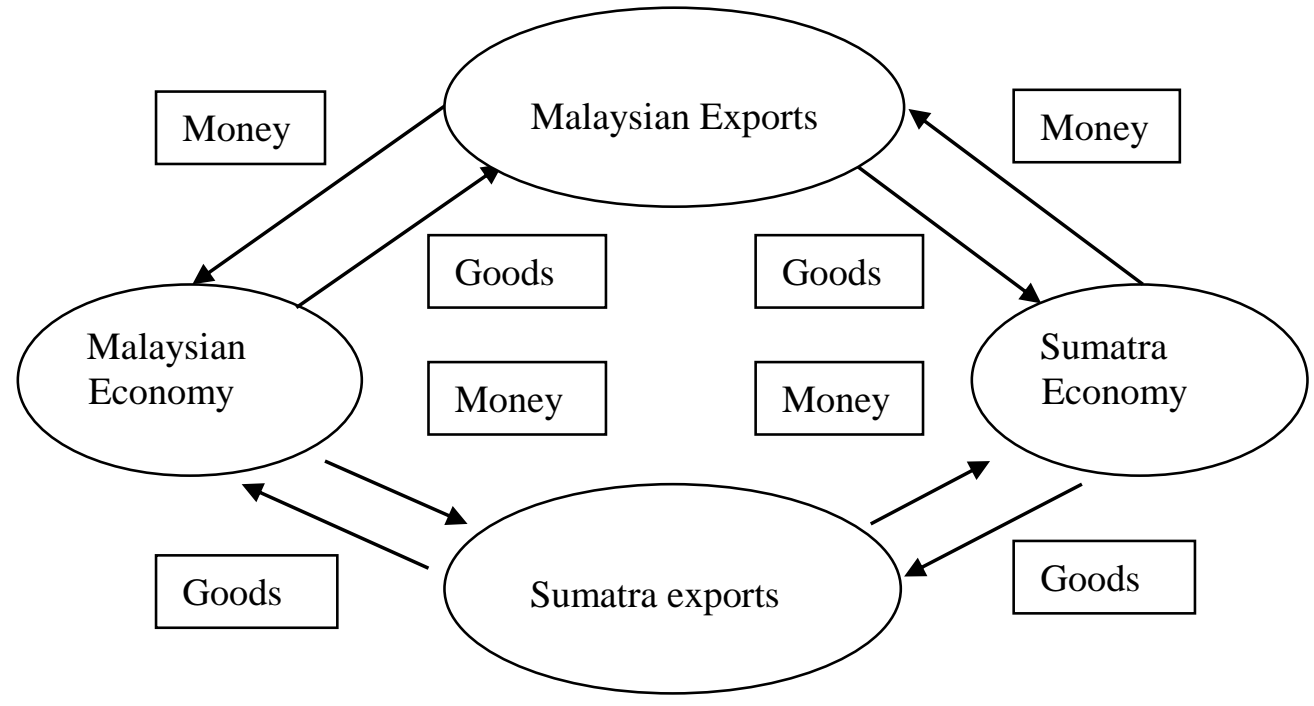


Export of North Sumatra to Malaysia is the trade in goods from North Sumatra to Malaysia from which money will flow to North Sumatra and this can improve the economy of North Sumatra. Likewise, Malaysian exports to North Sumatra are trading goods from Malaysia to North Sumatra from this activity flowing money from North Sumatra to Malaysia this increases Malaysia's economy.

\section{Methodology}

This study uses time series data from 1990-2016 sourced from BPS North Sumatra and the Malaysian statistic department. The model used to analyze import variables, is as follows:

ImportSu $=\alpha 0+\alpha 1$ PDRBSU $+\alpha 2 \mathrm{D}$ the value of the exchange rate $+\epsilon$

ImportMl $=\beta 0+\beta 1 \log \mathrm{PDBM}+\beta 2 \log$ value of the exchange rate $+\epsilon$

Where: ImportsSu: North Sumatra imports from Malaysia; ImportsMl: Malaysian imports from North Sumatra; PDRBSU: North Sumatra Economy; GDPM: Malaysian economy; Exchange rate: The value of the rupiah against the USD.

Other models used to analyze the interaction of North Sumatra economic variables, North Sumatra exports to Malaysia, Malaysia economics, Malaysia exports to North Sumatra are the following:

DYSU $=\alpha 0+1$ DYSUt- $1+2$ DEKSSUt-1+ 3DEKSPRMt-1+ 4DPDBMt $1+\epsilon 1$

$\mathrm{DEKSSU}=\beta 0+1 \mathrm{DEKSSUt}-1+2 \mathrm{DYSUt}-1+3 \mathrm{DEKSPRMt}-1+4 \mathrm{DPDBMt}-1+\epsilon 2$

DEKSPRM $=\gamma 0+1$ DEKSPRMt-1+ 2DEKSSUt-1+ 3DYSUt-1+ 4DPDBMt- $1+\epsilon 3$

DPDBM $=\lambda 0+1$ DPDBMt-1+ 2DEKSPRMt-1+ 3DEKSSUt-1+ 4DYSUt $-1+\varepsilon 4$

Where: DYSY: North Sumatra Economy; DEKSSU: Export of North Sumatra to Malaysia; DPDBM: Malaysian Economy; DEKSPRM: Malaysian exports to North Sumatra; $\rho$ : Optimal lag length.

\section{Results}

\subsection{North Sumatra Import - Malaysia and Otherwise}

North Sumatra's economy adheres to an open economy, import is one of the economic policies used to improve public welfare, from imports made by North Sumatra to get high-tech products from other countries and also get goods that have not been produced by North Sumatra. These goods include capital goods, auxiliary goods, and there are also consumer goods. The estimation of the import function of North Sumatra from Malaysia can be seen in Table 1. 
Table 1. Results of estimation of import function of North Sumatra from Malaysia

\begin{tabular}{|l|c|c|c|c|}
\hline \multicolumn{1}{|c|}{ Variable } & Coefficient & Standard Error & t-statistic & probability \\
\hline C & 9.971952 & 0.474539 & 21.01400 & 0.0000 \\
\hline $\begin{array}{l}\text { D Exchange } \\
\text { rate }\end{array}$ & $4.88 \mathrm{E}-05$ & 0.000132 & 0.369553 & 0.7151 \\
\hline PDRBSU & $1.87 \mathrm{E}-08$ & $4.95 \mathrm{E}-09$ & 3.77557 & 0.0010 \\
\hline R Squared & 0.384425 & & & \\
\hline
\end{tabular}

North Sumatra's imports from Malaysia are influenced by the North Sumatra economy which is positive and significant with a $99 \%$ confidence level and a 1.87 coefficient which means an increase of IDR 1,000 of the North Sumatra economy will increase North Sumatra's imports from Malaysia on average assuming other variables remain at US\$1.87. This illustrates that there is a match between empirical conditions and international trade theory that imports are a function of national income in a region. Increasing income in a region resulted in changes in the consumption level of the people in the region, namely the community trying to meet their consumption needs, especially those who have middle to lower income, they want products that use technology better, so far they consume products that use local technology. To get products that use better technology, imports from neighboring countries already have industries with modern technology applications. Furthermore, Malaysian imports from North Sumatra are also influenced by the Malaysian economy. Estimates of Malaysia's import function from North Sumatra can be shown in Table 2.

Table 2. Estimation of Malaysia's import function from North Sumatra

\begin{tabular}{|l|c|c|c|c|}
\hline \multicolumn{1}{|c|}{ Variable } & Coefficient & Standard Error & t-statistic & probability \\
\hline C & 7.669707 & 0.820309 & 9.349440 & 0.0000 \\
\hline Log PDBM & 1.030466 & 0.294297 & 5.01448 & 0.0018 \\
\hline $\begin{array}{l}\text { Log exchange } \\
\text { rate }\end{array}$ & 0.077224 & 0.173683 & 0.444626 & 0.6606 \\
\hline R. Squared & 0.708780 & & & \\
\hline
\end{tabular}

Malaysian imports from North Sumatra are influenced by the Malaysian economy which is positive and significant with a confidence level of $99 \%$ and a coefficient of 1.30466 which means that a $1 \%$ increase in the Malaysian economy will increase Malaysian imports from North Sumatra on average assuming other variables remain at $1.03 \%$. In the case of Malaysia, the condition of international trade is almost the same as the situation in North Sumatra, Malaysia's import variable from North Sumatra can be explained by Malaysia's national income, changes in Malaysia's GDP will increase public consumption and household consumption. Companies that 
have not reached the maximum capacity level try to optimize the production capacity they have, this they do to meet the increasing demands of the community. Increased production of industrial companies, the need for raw materials and auxiliary materials also increases. To meet this need, imports are made, especially raw materials for industrial companies whose raw material and auxiliary resources are from outside Malaysia. Malaysian imports from North Sumatra are dominated by primary goods including the production of the plantation sector, the forestry sector and the marine sector. This study shows that the economic improvement of two neighboring regions will increase trade relations between the regions, especially in the import sector. Yusuf (2009) explained that North Sumatra's economy was influenced by inter-provincial trade and foreign trade.

\subsection{Economic Interaction Analysis of North Sumatra - Malaysia}

The use of VAR or VECM models the first step that must be done is the stationary data test, the test is carried out using Augmented Dicky-Fuller (ADF), this test aims to avoid the results of Spurious Regression regression, from the data processing results obtained as in Table 3.

Table 3. Stationary Test Results for Economic Data of North Sumatra and Malaysia

\begin{tabular}{|l|c|c|c|c|c|c|}
\hline \multicolumn{1}{|c|}{ Variable } & Stationary & ADF & $\begin{array}{c}\text { Critical } \\
\text { Value 1\% }\end{array}$ & $\begin{array}{c}\text { Critical } \\
\text { Value } \\
5 \%\end{array}$ & $\begin{array}{c}\text { Critical } \\
\text { Value 10\% }\end{array}$ & Prob. \\
\hline $\mathrm{D}(\mathrm{YSU})$ & $1^{\text {st }}$ & -2.642101 & - & - & -2.632604 & 0.0982 \\
\hline $\mathrm{D}(\mathrm{Ekssu})$ & $1^{\text {st }}$ & -5.811299 & -3.724070 & - & - & 0.0001 \\
\hline $\mathrm{D}(\mathrm{PDBM})$ & $1^{\text {st }}$ & -4.713034 & -3.724070 & - & - & 0.0010 \\
\hline $\mathrm{D}($ Eksprm $)$ & $1^{\text {st }}$ & -3.916200 & -3.724070 & - & - & 0.0064 \\
\hline
\end{tabular}

Table 3 above explains the four stationary variables at first difference, D (YSU) 90\% confidence level, D (Ekssu) 99\% confidence level, D (GDPM) 99\% confidence level, and D (EXPR) 99\% confidence level. The next stage is the cointegration test to the four variables, from the data processing results obtained as in Table 4.

Table 4. Cointegration Test Results

\begin{tabular}{|l|c|c|c|c|}
\hline Hypo. no of CE(s) & Eigen value & Trace Statistic & 0.05 Critical Val. & Probability \\
\hline None & 0.940191 & 103.0351 & 47.85613 & 0.0000 \\
\hline At most 1 & 0.606303 & 38.25330 & 29.79707 & 0.0042 \\
\hline At most 2 & 0.411679 & 16.81345 & 15.49471 & 0.0315 \\
\hline At most 3 & 0.181708 & 4.612340 & 3.841466 & 0.0317 \\
\hline
\end{tabular}


Table 4 above explains the value of Trace Statistics to the four variables greater than the value of the critical value 0.05 , this shows that the four variables are cointegration. These results provide clues that the subsequent analysis model uses the VECM model.

\subsection{Impulse Response Function Analysis}

Impulse response test analysis is intended to determine the response of endogenous variables to shock from other variables in the VECM model. When visualized in the form of graphs the response to shock can be seen in Figure 3.

Figure 3. Response Graph of Variables in the VECM Model
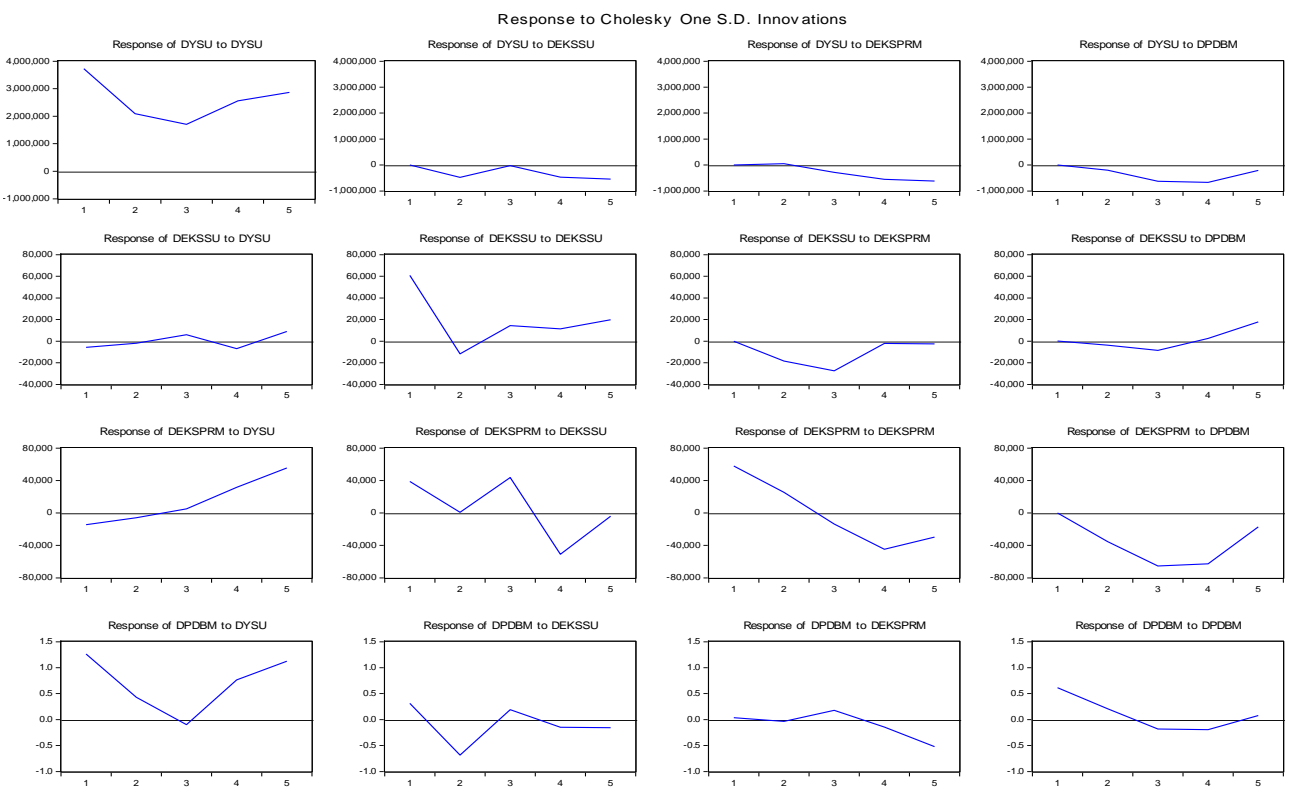

Graph 3a ( $1^{\text {st }}$ line) shows that the response of North Sumatra's economic variables due to the export variable shock of North Sumatra to Malaysia, the North Sumatra export variable shock to Malaysia caused the North Sumatra economy to decline at the beginning of the period and then climbed further down and then flat. Graph $3 \mathrm{~b}$ $\left(1^{\text {st }}\right.$ line) shows that the economic response of North Sumatra due to the shock of the Malaysian export variable to North Sumatra caused the North Sumatra economy to change horizontally at the beginning of the period and then decrease and then flat at the end of the period. Graph $3 \mathrm{c}\left(1^{\text {st }}\right.$ line $)$ shows that the economic response of North Sumatra due to the shock of the Malaysian economic variables caused the North Sumatra economy to decline slowly then experienced an increase at the end of the period. Graph 3d ( $1^{\text {st }}$ line) explains that the response of North Sumatra's exports to Malaysia due to the shock of North Sumatra's economic variables caused North 
Sumatra's exports to Malaysia to increase slowly and then decline and then rise again at the end of the period.

Graph 3e ( $2^{\text {nd }}$ line) shows that the response of North Sumatra's exports to Malaysia due to the shock of Malaysian exports to North Sumatra caused the export of North Sumatra to Malaysia at the beginning of the period to decline sharply and then rose in the middle of the next period horizontally at the end of the period. Graph $3 \mathrm{f}\left(2^{\text {nd }}\right.$ line) shows that the response of North Sumatra's exports to Malaysia due to the shock of Malaysia's economic variables caused North Sumatra's exports to Malaysia to slope slightly at the beginning of the period until the middle of the period and then increase at the end of the period. Graph $3 \mathrm{~g}\left(2^{\text {nd }}\right.$ line $)$ explains that the response of Malaysian exports to North Sumatra due to the shock of North Sumatra's economic variables caused Malaysian exports to North Sumatra to move up from the negative region to positive territory. Graph $3 \mathrm{~h}\left(2^{\text {nd }}\right.$ line $)$ shows that the response of Malaysian exports to North Sumatra due to the shock of the North Sumatra export variable to Malaysia caused Malaysian exports to North Sumatra to move down then rise further down to negative territory then move up.

Graph $3 \mathrm{i}\left(3^{\text {rd }}\right.$ line) shows that the response of Malaysian exports to North Sumatra due to the shock of the Malaysian economy caused Malaysian exports to North Sumatra to move down at the beginning of the period and then flattened amid the next period moving up at the end of the period. Graph $3 \mathrm{j}$ ( $3^{\text {rd }}$ line) explains that Malaysia's economic response due to the economic shock of North Sumatra caused Malaysia's economy to move down and then amid the rising period until the end of the period. Graph $3 \mathrm{k}$ ( $3^{\text {rd }}$ line) shows that Malaysia's economic response to the shock of North Sumatra's exports to Malaysia caused Malaysia's economy to move down and then move up past the positive boundary and then down and flat at the end of the period. Graph 31 ( $3^{\text {rd }}$ line) shows that Malaysia's economic response to the shock of Malaysian exports to North Sumatra caused Malaysia's economy to move flat at the beginning of the period and then move up slowly and then move down at the end of the period.

\subsection{Granger Causality Analysis}

Granger causality analysis aims to determine the direction of the relationship of the four variables, in addition to looking at the relationship between North Sumatra (DYsu) economic variables, North Sumatra export variables to Malaysia (DEkssu), Malaysia export variables to North Sumatra (DEksprm) and Malaysian economic variables (DPDBM) namely whether these variables improve the performance of each variable, along with a table of 5 granger causality test summaries.

Table 5. Granger Causality Test

\begin{tabular}{|l|l|l|l|l|l|}
\hline Null Hypothesis (h0) & OBS & F statistics & Prob & Result & Direction \\
\hline
\end{tabular}




\begin{tabular}{|l|c|l|l|l|l|}
\hline $\begin{array}{l}\text { Dekssu does not grenge } \\
\text { cause Deksprm }\end{array}$ & 24 & 8.76383 & 0.0020 & Reject $\mathrm{H}_{0}$ & $\begin{array}{l}\text { two way } \\
\text { relationship of } \\
\text { Dekssu and } \\
\text { Deksprm }\end{array}$ \\
\hline $\begin{array}{l}\text { Deksprm does not } \\
\text { grenge cause Dekssu }\end{array}$ & 24 & 3.47076 & 0.0519 & Reject $\mathrm{H}_{0}$ & $\begin{array}{l}\text { two way } \\
\text { relationship }\end{array}$ \\
\hline $\begin{array}{l}\text { Dpdbm does not grenge } \\
\text { cause Deksprm }\end{array}$ & 24 & 0.70044 & 0.5087 & Accept $\mathrm{H}_{0}$ & $\begin{array}{l}\text { one way } \\
\text { relationship }\end{array}$ \\
\hline $\begin{array}{l}\text { Deksprm does not } \\
\text { grenge cause Dpdbm }\end{array}$ & 24 & 3.35380 & 0.0566 & Reject $\mathrm{H}_{0}$ & $\begin{array}{l}\text { two way } \\
\text { relationship }\end{array}$ \\
\hline $\begin{array}{l}\text { Dpdbm does not grenge } \\
\text { cause Dekssu }\end{array}$ & 24 & 0.19153 & 0.8273 & Accept $\mathrm{H}_{0}$ & $\begin{array}{l}\text { one way } \\
\text { relationship }\end{array}$ \\
\hline $\begin{array}{l}\text { Dekssu does not grenge } \\
\text { cause Dpdbm }\end{array}$ & 24 & 2.95714 & 0.0782 & Reject $\mathrm{H}_{0}$ & $\begin{array}{l}\text { one way } \\
\text { relationship }\end{array}$ \\
\hline
\end{tabular}

Table 5 shows that exports of North Sumatra to Malaysia (DEKSSU) caused Malaysian exports to North Sumatra (DEKSPRM) whereas Malaysian exports to North Sumatra caused North Sumatra exports to Malaysia. This shows that the two variables mutually improve the performance of each variable, meaning there is a two-way relationship. Furthermore, the Malaysian economy (DPDBM) did not cause Malaysian exports to North Sumatra (DEKSPRM), whereas Malaysian exports to North Sumatra caused Malaysia's economy, this showed Malaysian exports to North Sumatra improved Malaysia's economic performance, meaning there was a one-way relationship. Furthermore, that the Malaysian economy (DPDBM) did not cause North Sumatra's Export to Malaysia (DEKSSU) then North Sumatra's exports to Malaysia caused Malaysia's economy, there was a one-way relationship.

\section{Conclusion}

Based on the analysis that has been done, several important findings can be made. An increase of IDR 1,000 of North Sumatra's economy increased Sumatra's imports from Malaysia on average by US \$ 1.87. This shows improvement for the Malaysian economy. An increase of US \$ 1 from the Malaysian economy increases Malaysian imports from North Sumatra on average by Rp1030, - this condition improves the economic performance of North Sumatra.

VECM analysis shows that North Sumatra's exports to Malaysia are influenced by the Malaysian economy at a 95\% confidence level. Malaysian exports to North Sumatra are affected by the economy of North Sumatra at lag-1 with a $95 \%$ confidence level. Then it was also affected by North Sumatra exports to Malaysia at a 95\% confidence level. The Malaysian economy is influenced by the North Sumatra economy at a $90 \%$ confidence level. Then it was also influenced by North Sumatra exports to Malaysia at a $90 \%$ confidence level. Granger causality analysis results show that there is a two-way export relationship between North Sumatra and Malaysia to Malaysian exports to North Sumatra. Furthermore, there is a one-way relationship between Malaysian exports to North Sumatra to the Malaysian 
economy. On the other hand, there is a one-way export relationship of North Sumatra to Malaysia against the Malaysian economy. Based on the results of the research that has been carried out, it can be suggested that the Government and entrepreneurs must carry out activities that can maintain the balance of import activities from North Sumatra and Malaysia. It is shown that the import activities of both regions are mutually beneficial. Furthermore, the export activities of the two regions can explain the economies of the two regions, so that each region increases their export activities so that mutualistic symbiosis can be maintained and may even be increased.

\section{References:}

Athukorala, P.C. and Yamashita, N. 2006. Production fragmentation and trade integration: East Asia in a global context. The North American Journal of Economics and Finance, 17(3), 233-256.

Audretsch, D., Maryann, B.J., and Feldman, P. 2004. Knowledge Spillover and the Geography of innovation, Toronto, Canada: Indiana University and centre for Economic Policy (CEPR) University of Toronto.

Bendavid-Val, A. 1991. Regional and Local Economic Analysis for Practitioners. New York: Greenwood Publishing Group, Inc.

Cheshire, P. and Carbonaro, G. 1996. Urban economic growth in Europe: testing theory and policy prescriptions. Urban Studies, 33(7), 1111-1128.

Glaeser, E.L., Kallal, H.D., Scheinkman, J.A. and Shleifer, A. 1992. Growth in cities. Journal of political economy, 100(6), pp.1126-1152.

Mody, A. and Wang F.Y. 1997. Explaining Industrial Growth in Coastal China: Economic Reforms and What Else? The Word Bank Economic Review, 11(2).

Nasir, M. 2017. An Analysis of Mutual Relationship Between the Province of North Sumatra in Indonesia and Singapore Economies. International Journal of Economic Research, 14(4).

Rahman, M.M. 2008. Macro Economic and Trade Link Models of SAARC Countries: an Investigation for Regional Trade Expansion. Journal of the Asia Pacific Economy. 13.

Wijaya, E., Nopiandri, K. and Habiburrokhman, H. 2017. Dinamika Upaya Melakukan Sinergi Antara Hukum Perdagangan Internasional Dan Hukum Lingkungan. Jurnal Hukum dan Peradilan, 6(3), 487-508.

Yusuf, M. 2009. Analysis of inter-regional and foreign trade and its effects on the economy of North Sumatra Province. Unpublished Thesis Thesis, Syiah Kuala University Darussalam Banda Aceh. 